\title{
GOTHIC LONDON: ON THE CAPITAL OF URBAN FANTASY IN NEIL GAIMAN, CHINA MIÉVILLE AND PETER ACKROYD
}

\author{
ARno Meteling \\ University of Cologne \\ arno.meteling1@uni-koeln.de
}

Recibido: 09-05-2017

Aceptado: 23-11-2017

\section{ABSTRACT}

There are good reasons to call London the capital of urban fantasy. Like no other city it embodies an intertwinedness of enlightenment and modernity with notions of the occult, the mythical and the magical. The idea of an urban underworld that somehow is the dark mirror of the city is central for the depiction of a fantastic London. I will look into three examples of urban fantasy: Neil Gaiman's novel Neverwhere (1996), China Miéville's story «Reports of Certain Events in London» (2004), and Peter Ackroyd's novel Hawksmoor (1985) that portray London as a liminal space and a gothic heterotopia.

Key words: London, urban fantasy, Neil Gaiman, China Miéville, Peter Ackroyd, heterotopia.

\section{RESUMEN}

Hay buenas razones para denominar a Londres la capital de la fantasía urbana. Como ninguna otra ciudad, encarna un entrelazamiento de la ilustración y la modernidad con las nociones de lo oculto, lo mítico y lo mágico. La idea de un submundo urbano que de alguna manera es el espejo oscuro de la ciudad resulta central para la representación de un Londres fantástico. Examinaré tres ejemplos de fantasía urbana: la novela Neverwhere (1996), de Neil Gaiman, el relato «Reports of Certain Events in London» (2004), de China Miéville, y la novela Hawksmoor (1985) de Peter Ackroyd, que retratan Londres como un espacio liminal y una heterotopía gótica.

Palabras Clave: Londres, Neil Gaiman, China Miéville, Peter Ackroyd, heterotopía. 


\section{On EPIC AND URBAn FANTASY}

The beginning of the fantasy genre can not be pinpointed. At the very least, modern fantasy — like all genres - can be understood as the history of accumulated figures, motifs, tropes and narrative procedures. Influences can be found in ancient mythologies and religious writing as well as in texts at the beginning of Western literary history -in epics like the Iliad and the Odyssey as well as in mediaeval romances about knight-errants and their adventures. Novels of the eighteenth century about knights, adventures, ghosts and secret societies as well as the romanticism of the early nineteenth century can be regarded as direct precursors. Furthermore, modern fantasy since the late nineteenth century often oscillates between and combines the fantastic with the realism of the historical novel.

At the end of the twentieth century fantasy literature seems to be dominated by two very different traditions or sub-genres - the «epic» or «high fantasy» on the one hand and the «weird» or «urban fantasy» on the other (Mendlesohn \& James, 2009: 255). The epic fantasy, most popularly represented by J.R.R. Tolkien's novel The Lord of the Rings (1954-1955), is characterized in short by the themes of the heroic journey (Campbell, 2008) and epic war (Meteling, 2016). Furthermore, it is about the establishment of an orderly, coherent and closed world, a «Secondary World» (Tolkien, 2006: 140), usually decorated with mediaeval trappings. In contrast, urban fantasy is a hybrid of different traditions and styles, in which a modern and civilized high-tech world - essentially marked as our world, the «Primary World»-, is combined with fantastic characters or another fantastic world. The urban fantasy's narrative is almost always about the confrontation of the fantastic and realism. It ponders on the concepts of borders, perspectives and liminality thriving on the contrasts and possibilities of the clashes. Famous examples of urban fantasy are written by Neil Gaiman (Neverwhere, 1996, American Gods, 2001, Anansi Boys, 2005), China Miéville (King Rat, 1998, Un Lun Dun, 2007, The Kraken, 2010), Clive Barker (Weaveworld, 1987, Imajica, 1991, Abarat, 2002) or by Stephen King and Peter Straub in The Talisman (1984) and Black House (2001).

The English writer Michael de Larrabeiti can be regarded as one of the most important precursors of a tradition that may be called «London Urban Fantasy». He is the author of the seminal Borrible Trilogy, which explore the adventurous albeit dangerous and dark side of London from 1976 to 1986 (Larrabeiti, 2002). In a nutshell, the Borrible books present a thorough discussion of the Peter Pan trope. They are about children who have left their homes and live 
under the city of London on the fringes of society - more or less like homeless people with a tribal spin. The borribles are persecuted by the police who wants to bring the children back into society and thus to a boring, controlled and bourgeois life. Successively these children's bodies transform- further distancing them from human's civilized society. Eventually, they develop pointy ears, becoming elf-like or resembling some depictions of Peter Pan.

According to Michael Moorcock (1978), fantasy literature can be divided into two traditions: on the one hand there is the romantic, antimodern and apolitical fantasy, represented by the likes of C. S. Lewis (The Chronicles of Narnia, 1950-1956), Richard Adams (Watership Down, 1972) and Tolkien. It is predominantly concerned with a «vanished» idealized rural world and «sentimentality» (Moorcock, 1978: 2). Fredric Jameson's postmodernist concept of «nostalgia» (Jameson, 1991: 279-296) may come to mind here. Moorcock identifies this fantasy as «corrupted romanticism» (Moorcock, 1978: 5) and as the product of a conservative Anglican Toryism. It serves as social affirmation and means of escapism rather than criticism. On the other hand, there is a tradition that, mirroring the New Wave in science fiction literature, focuses on the political, the contemporary and the urban. Exemplary writers are -in Moorcock's perspective- Ursula K. LeGuin (Earthsea series, 1968-2001, Hainish series, 19662000), Alan Garner (Elidor, 1965, The Owl Service, 1967), and Terry Pratchett (Discworld series, 1983-2015). Despite Moorcock's denial that the first tradition is by any means like a «romance, let alone an epic» (Moorcock, 1978: 2), his concept of two different and mutually exclusive fantasy traditions can easily be identified with the two sub-genres already mentioned — «epic fantasy» and «urban fantasy».

According to Moorcock's definition urban fantasy functions as a counterpoint to the idyllic and ahistorical hermetic secondary worlds in epic fantasy, establishing some kind of «reality principle» (Freud, 1991: 36) in fantasy writing. Therefore, urban fantasy should be about contemporary problems and the hardships of (post-)industrialized modernity, it should be about society and politics and it especially should be about living in an urban environment, in a big city. Poetologically, one could add, urban fantasy discusses the juxtaposition of a world portrayed as realistic and referential and the self-referential world of the fantastic and of miraculous events and characters. While epic fantasy - like all literature - cannot exist without referential aspects and, for example, also has to deal with concepts of society, politics and war, it is done only in an allegorical way. Despite Tolkien's famous denial of an allegorical or topical reading of The Lord of the Rings (Tolkien, 1991: 10), it is, for 
example, perhaps unavoidable to interpret the war not as some depiction of World War One or Two. In urban fantasy contemporary subjects and developments are portrayed in a much more literal way. Urban fantasy is more like science fiction literature in the way that it presents alternatives to our modern lives - be it social, political or cultural or generally referring to our understanding of reality and perception.

However, above all it is the notion of spatiality that characterizes urban fantasy. If epic fantasy is about - maybe dwindling - pastoral landscapes, one of the definitive features of urban fantasy are spaces that can be recognized as parts of our contemporary world or at least as versions or interpretations of them. Urban fantasy is about cemented roads, technological means of transport and about borders and transitions, about how to get from one place to another. So, urban fantasy is especially about looking at transitions, at the boundaries between the worlds of realism and of the fantastic and at characters who are go-betweens, who - like the heroes in ancient myths and epicsare able to switch between these places and between different planes of existence, be it Heaven or Hell, Elysium or Tartarus. Furthermore, it is often the case that these worlds or planes occupy the same space so that the fantastic is less a question of place but rather one of perception or state of consciousness.

\section{The Underside of London: Neil Gaiman's NeVErWhere}

Comic and fantasy author Neil Gaiman's debut novel Neverwhere (1996) is the literary adaptation of his eponymous BBC television series. The story begins when the young Scotsman Richard Mayhew moves to the city of London. Still in his hometown, he is in a prophetic way warned by an old homeless woman about London and about doors: «I'd watch out for doors if I were you». (Gaiman, 2016: 3) In a proleptic way she also mistakenly thinks he is homeless, too. Later - Mayhew already lives and works for some time in London- he walks with his fiancée Jessica to the Modern Tate Museum. On their way they stumble upon an injured girl lying on the street. Jessica, who needs to meet an important customer, wants to ignore her, but Mayhew helps the girl who is called «Door», takes her to his home and unknowingly enters a parallel world - London Below, the underside of the city.

In the tradition of the heroic journey as it is described by Joseph Campbell (Campbell, 2008), Mayhew meets fantastic creatures, friends and mentors like Door, Anaesthesia, the Marquis de Carabas and the treacherous Hunter as 
well as opponents like the two predator-like killers Croup and Vandemar and their employer, the fallen angel Islington. Above all, the characters have to fulfil quests which, like the adventures in a mediaeval romance or in a video game, are segmented into various separate tasks. For example, Mayhew has to get a key from the Black Friars, and in their abbey, he has to pass a test like an ancient hero or a knight-errant in a King Arthur story, for the «ordeal» (Gaiman, 2016: 272) for him is not a physical one but is addressed at his character. Finally, like mythical Theseus, Mayhew even defeats a monster in a labyrinth, the great beast of London, with the help of Hunter and her magical spear (Gaiman, 2016: 317-354).

Neverwhere's story is in many aspects based on the conventions of ancient mythology and probably even more of epic fantasy. But the tropes of fantasy all come with a twist, are normalized or just hinted at, and the novel often uses them to deal with very contemporary discourses, such as politics of identity, for example. Door, the injured girl who sets everything in motion, seems to be subjected to some kind of racial formatting epic fantasy usually employs, so when her «elfin face» (Gaiman, 2016: 79) is described, she is clearly no elf but simultaneously a normal human being and something very different. The evil henchmen Croup and Vandemar seem to be some sort of werefox and werewolf respectively, but this is never spelled out. The vampires called «velvets» are special as they are no Dracula-type vampires but refer to the folkloric lamia-vampires or to the cannibalistic queen from Greek mythology. Even the beast in the labyrinth is no minotaur but has qualities of an ox as well as those of a giant boar. The characters' gender and skin colour are highlighted in the narrative and stress the diversity of the characters, when, for example, it is emphasized that Hunter has a skin «the color of burnt caramel» (Gaiman, 2016: 135) and the Marquis de Carabas possesses an «extremely dark face» (Gaiman, 2016: 52). Gender roles are also somehow inverted as, for example, the female warrior Hunter is physically without any doubt superior to the novel's hero Mayhew. So the role of heroic fighting is fulfilled by a woman, right up to the conflict with the beast of the labyrinth.

Maybe even more importantly is the fact that the story of the main character Mayhew is not his own. He is only an agent, an effect of the character Door who wants to solve and avenge the murder of her family. Nevertheless, in a very conventional way Neverwhere is a novel about the development of the hero throughout his heroic journey. Mayhew does not develop any initiative of his own in his surface life and almost always behaves like a child. Not only does he collect magic trolls on his desk, he does not even like them. 
He is simply not able to convey the truth to his friends and colleagues, so they keep giving him these figures as presents. Above all this, he obeys his fiancée Jessica in all aspects of his life. She is the one who dictates his behaviour and personal preferences. It is Mayhew's adventures in the dangerous underworld of London that change him. Starting with the rescue of Door against Jessica's will, he slowly becomes an adult developing a mind of his own. This leads right up to his two final decisions at the ending of the story: his wish to return to the upper world and thus to regain his old life, something that surprisingly turns out better than before, only to acknowledge that a bourgeois life in London does nothing for him and then finally returns to London Below.

The society of this London underworld does seem fairly conventional in an epic fantasy way for it is organized like a mediaeval feudal system. But like the trope of the heroic journey this social system is not used without any comment, either. It might be on the brink of a revolutionary change as Door's father, the Baron Portico, has planned to «unite London Below, to unite the baronies and fiefdoms, bond with London Above» (Gaiman, 2016: 324). Also, the underworlds's Earl and his court live rather poorly in a railway waggon. So the fake-mediaeval trappings of epic fantasy are - one could say: in a satirical way - modernized and thereby maybe undermined and questioned. The objects the characters find and use are another aspect that somehow reflects an epic fantasy world but is twisted. Similarly to the characterization of the people who dwell in London Below the underside is a place for the stolen, the forgotten and the abandoned. It is clearly the dump for London society's trash from above. But it is exactly this mix of «lost property» (Gaiman, 2016: 123) that leads to an interestingly heterogeneous collection of objects in the world of London Below, objects that seem to come from the fake-mediaeval discourse of epic fantasy as well as from modern context. The warrior Hunter, for example, uses a magical spear, a quarterstaff and a knife — but also a flashlight (Gaiman, 2016: 113). In the floating market one can find objects as diverse as antique radios or the «hand of glory», as described in hermetic and occult discourses. Furthermore, there is no currency in London Below. The floating market where everyone is selling and buying goods is a trading market.

Urban fantasy's decisive difference to epic fantasy is the setting - namely contemporary London, its underworld and, above all, its Underground, the «tube» (Gaiman, 2016: 152), where «commuters [are] wandering the tunnels» (Gaiman, 2016: 152). Neverwheres's setting is mostly subterranean, therefore echoing the dark corridors and dungeons of the gothic novel. The characters go through «deep tunnels» (Gaiman, 2016: 104), built during 
World War Two, or even into London's «sewer» (Gaiman, 2016: 140) or enter the «labyrinth», «one of the oldest places in London Below» (Gaiman, 2016: 339). Yet this obscure parallel world is somehow a reflection of the world above. It is understood as a strange «unreal mirror of (...) London» (Gaiman, 2016: 136), a notion that can easily be read as a self-referential comment about London as it is depicted in the novel. Rhetorically, this mirror works with plays on words and speaking names for they represent buildings or spaces in London, thereby anthropomorphizing them. «Knightsbridge» (Gaiman, 2016: 103) becomes the dark and dangerous «Night's Bridge» (Gaiman, 2016: 114), the character «Old Bailey» takes his name from the well-known central criminal court building in London, and the «Angel, Islington», the name of the novel's villain, is a famous landmark in London as well. «Door», her mother «Portia» and her father «Portico», who revealingly all bear the same name, carry their supernatural ability to open all doors in their names like in a fairy-tale. Finally, the name of every «underground station» (Gaiman, 2016: 142) shows what is to be found there. There are shepherds at «Shepherd's Bush» (Gaiman, 2016: 151) while the angel Islington is to be found at «Angel station» (Gaiman, 2016: 147) in Islington. Furthermore, the Underground is so important that there is not only a special edition of the novel for an American readership, which gives additional information about it, but there is also a map of the underground network printed in the book - just like the maps of fictitious worlds in epic fantasy novels (Meteling, 2016).

Neverwhere - like every literary text - can be read in several ways. On the one hand it obviously is about social differences and the contradictions between the «possessors above us, and the dispossessed, we who live below and between, who live in the cracks» (Gaiman, 2016: 108). The people living in London Below can allegorically be read as society's losers. The Underside of London is a refuge for the underprivileged and the homeless, the people who have fallen through the «cracks» of urban society - or as the Marquis curiously puts it in a more ontological manner: «Young man, (...) understand this: there are two Londons. There's a London Above - that's where you lived - and then there's London Below - the Underside - inhabited by the people who fell through the cracks in the world» (Gaiman, 2016: 140). So in Neverwhere London is literally divided vertically taking its cue from the trope of the «they above» versus «we below». It is also about the mythical heroic journey of katabasis that not only prefigures this concept but is the secret drive of the narrative as well for it is always about getting above or below. The hero Mayhew wants nothing more than to get back to the upper-side of London 
while the villainous angel Islington - like the original fallen angel Lucifer in John Milton's epic Paradise Lost (1667) — wants to go back to Heaven. Regarding the spatial confinements the characters are in it is striking that the novel is not only about the differences between the rich and the poor and their social positions, echoing a vertically oriented class theory, but it is also about the asymmetry of perception. While the inhabitants of the Underside of London perceive and observe upper London's inhabitants, people from London Above are not able to perceive or recognize people from Below as soon as they belong to this underworld. Jessica, for example, no longer recognizes her fiancé Mayhew, even when he directly talks to her (Gaiman, 2016: 211-214).

In Neverwhere - as the title conveys - the politics of society as well as personal identity are bound to the notion of space. Of special importance is the concept of verticality which is derived from social or economic discourses and marks the difference between the characters. While the emphasis on the subterranean space echoes the tradition of gothic literature, the verticality curiously mirrors H. G. Wells' science fiction novel The Time Machine (1895), which is a social novel as well. In the far future, the novel describes, the childish Eloi do not know anything about their world. They live in luxury and blissful ignorance. Their food and lifestyle is provided by the Morlocks, degenerated troglodyte-like descendants of the working class who live underground. The secret behind this arrangement is that the Morlocks breed and batten the decadent Eloi like cattle and eat them. The main difference between Neverwhere and this novel is, of course, the topography of sovereignty, because in The Time Machine authority is inverted as it is the workers who rule from the underground. $\mathrm{Ne}$ verwhere does not invest that much thought into revolution or the structures and possible changes of society but is more interested in the development of the characters living in this world. Therefore, it still continues traditions that are usually attributed to conventional fantasy —albeit in a modern and urban way. So, it does not only present itself as an «unreal mirror» (Gaiman, 2016: 136) of London or of reality but also of a genre called «epic fantasy».

\section{The Secret Wildlife of London: China Miéville's «Reports of Certain EVENTS IN LONDON»}

China Miéville is one of the most prominent writers of urban fantasy. His three novels about the city of New Crobuzon in the alien world of BasLag are probably the most popular ones: Perdido Street Station (2000), The Scar 
(2002) and The Iron Council (2004). The setting of Bas-Lag is a mix of different figures, narratives and tropes (topoi) from science fiction, steampunk, fantasy and horror. In addition to describing technically advanced inventions, modern civilization and alien species it also has magic and demons — all rolled up in an urban environment, the sprawling metropolis of New Crobuzon. The description of this multicultural, baroque and labyrinthine moloch shows how different urban fantasy is to epic fantasy and accentuates the political, social and cultural aspects of Miéville's writing. There is no monarchy in the city, no absolutist rule, as in most mediaeval-like epic fantasy, but an opaque oligarchy with several factions, which cooperate, but above all, scheme against each other.

Some of Miéville's novel titles such as The City \& the City (2009) and Embassytown (2011) explicitly stress the importance of urbanity. Some of his texts are also clearly located in London, such as the youth novel Un Lun Dun (2007) that operates with the urban fantasy trope of the dark side of a city, namely the eponymous "UnLondon» as the mirror of the London we know. The novel The Kraken (2010), some stories and his novellistic debut King Rat (1998) are also set in London, especially in a specific London parallel-, under- or mirrorworld. King Rat, for example, interweaves mythical and fairytale elements such as animal gods, especially Anansi, the spider god, and Loplop, the bird god, and the history of the Pied Piper of Hameln, with a modern setting clearly represented by the club culture of London in the late twentieth century.

Miéville's story «Reports of Certain Events in London» was first published in McSweeney's Enchanted Chamber of Astronomy Stories (2004), edited by Michael Chabon, and then later reprinted in Miéville's anthology Looking for Jake (2005). The title conveys a documentary story, a «report» of events based in London. So there is the notion of reality and referentiality right at the beginning. This is continued by using exact dates as well as a first-person narrator who is identified as China Miéville the writer. The first sentence is: «On the $27^{\text {th }}$ of November 2000, a package was delivered to my house» (Miéville, 2005: 55). This strategy of authentication is even more reflected by the style of the story, which starts with a narrative framing. In the tradition of the editor's fiction - a device that is used, for example in gothic fiction of the eighteenth century like in The Castle of Otranto as well as in postmodern novels such as Umberto Eco's The Name of the Rose (1980) — the narrator Miéville who lives in London in the «-ley Road» (Miéville, 2005: 55) receives a package with various documents. It is obviously a misunderstanding because the papers are 
directed to a certain Charles Melville who lives in the «-ford Road» (Miéville, 2005: 55). The content of this package, which mainly consists of letters, is transcribed in this report. The authenticity of this transcription is even more stressed by its reproduction in a facsimile way, including different fonts and simulated handwriting. There are the notes of observations, charts and also transcriptions of photographs (Miéville, 2005: 64).

For the most part of the story the reader is wondering what really is happening in this convoluted collection of letters and other documents. There are a lot of abbreviations and obscure references in addition to the fact that it is very heterogeneous material and its subject is quite confusingly about the living streets of London. But what becomes clearer and clearer is that the main part of the text is the correspondence between members of a secret society, especially between Charles Melville and Edgar Nugen. This society is called the «BWVF» (Miéville, 2005: 74) or «Brotherhood of Witnesses to / Watchers of the Viae Ferae» (Miéville, 2005: 74). The mission of this more or less cryptozoological group seems to be the observation of strange creatures called «viae ferae», «rues sauvages» or «wild streets». These names —as it becomes more transparent during the story - are meant to be understood quite literally. There are streets that are alive, moving and even travelling — within cities, but also between cities and even crossing national borders. Most of the time they seem to exist together peacefully, wandering whale-like through the cityscapes. Yet they also mate, fight and hunt each other.

One of the conclusions drawn in the letters is that there is an «antagonistic» relationship between «Stay Street» and «Varmin Way» or «VW» (Miéville, 2005: 65) as it called sometimes. The rivalry or fight between these two streets has been observed since the «early 1700s» (Miéville, 2005: 65). Nevertheless, the history of living streets seems to be even older. Since the fourteenth century "errant alleyways» are watched. It is even assumed that this has been the case since the beginning of the existence of roads: "Viae are fighting, and I think they always have». This is Nugen's «bellum theory» (Miéville, 2005: 67). The internationality of the wild streets, which do not care about national boundaries, is also given attention. There is, for example, the «Ulica Nerwowosc», a «visitor from Krakow» (Miéville, 2005: 67) that attends London. A chart that lists viae ferae-related events (Miéville, 2005: 67) underlines the scientific nature of the secret society's writing project. Their task is one of positivistic recording and classification in an enlightened Linnéan tradition. The classifying and scientific language of the secret observers is similar to zoological descriptions referring to wild ani- 
mals in their habitats. The letters and note are not about the complexity of modern life in the city but rather about simple wildlife in a natural environment, like a desert or a jungle. In addition to this cryptozoological discourse the text also refers to genealogy because the main object of study, the Varmin Way, is marked as the child of «Potash Street» and the «Luckless Road» which «courted and mated» (Miéville, 2005: 71).

Interestingly, one metaphor used for this peculiar lifeform is that of the rat, for example one street is called a «rat of a street» (Miéville, 2005: 66). Moreover, streets are regarded as a horde or a swarm, appearing as a strain of vermin: «Beware - Touch a rat and he will bite, as others have found, of our town and of the Vermin's vagrant tribe» (Miéville, 2005: 66). As the rat is the ultimate parasite of the urban space, responsible for the Black Plague in the Middle Ages and used as a defamatory allegory for the Jews in German National Socialism, the streets are definitely regarded as dangerous animals and monsters. The main rhetorical figure in this story is the personification and animation of streets. They are staged as living beings that, at least, have animal intelligence. As animals not only is their «morphology» (Miéville, 2005: 63) addressed, but quite graphically also their «innards» (Miéville, 2005: 63).

An important intertextual reference in this story is Herman Melville's novel Moby-Dick; Or, The Whale (1851). The name of the actual addressee of the package, Melville, refers to this author, of course. But the spelling is also similar to the name of the narrator and writer of the story, Miéville. The story also deals with the notion of hunting great, incomprehensible creatures - among them the Varmin Way, the most frequently mentioned and elusive street. A variation of this motif is found in the last chapter: «I can't know whether Charles Melville has broken Varmin Way, has tamed it, riding it like a bronco through the city and beyond». (Miéville, 2005: 77) So the question is if Man is able to domesticate and master the wild streets and even be transported by them like a sandworm in Frank Herbert's science fiction novel Dune (1965). The «feral streets», whether referring to a sperm whale as in Moby Dick or a sandworm in Dune, also refer to the Leviathan, the biblical monster, often depicted as a whale, and the allegory of civilized society in Thomas Hobbes' famous eponymous work about human politics and society (1651). Regarding the subject but even more the story's composition another reference can also be traced to Howard Phillips Lovecraft. One of his most famous stories «The Call of Cthulhu» (1928) is about a giant Leviathan-like monster living in the sea that is worshipped by several cults all over the world. The story surrounds the core of its narrative with several layers of other stories, sightings and 
notes, so «The Call of Cthulhu» is first and foremost about research and library work, about philological activities like collecting, writing, finding, comparing and reading old documents until the monster - more or less then a creature from the archives - becomes apparent. One final parallel between the whale and the feral streets of this «Report» lies in their hybrid nature: they are giant animals mistaken for a part of the environment, the ground on which people can stand, walk and live on. This is alluded to in the story's final words that refer to the «First Voyage of Sinbad the Sailor» in the Arabian Nights: «I think on another idea that this is not an occurrence but an unoccurrence, that Charles has woken - ley Road my home out of domesticity, and that it is yawning, and that soon it will shake itself off like a fox and sniff the air and go wherever the feral streets go when they are not resting, I and my neighbours tossed on its back like fleas» (Miéville, 2005: 77).

One could also read the report as the fantastic continuation of the flâneur, a nineteenth-century subject in literature - and especially in surrealism - or in the theoretical work of Walter Benjamin on the city (Benjamin, 1992). While in these texts the stroller, wanderer or stalker experiences the city as mythic and alive, walking through the streets like in a labyrinth, in Miéville's scenario it is a part of the city's infrastructure, namely the streets which become alive and behave like mythical monsters. Agency is transferred to space, and the singular genius loci of some space or a whole city is transferred to a horde of wild and animalistic streets. Ultimately, it is about more than the animation of dead objects for it is the abstract notion of «space» that becomes alive and even gets a name and a personality. Space gets to be an individual actor, an active part of the actor-network as described by Bruno Latour (2007). There is still the concept of the human actor and flâneur in the story, for the narrator systematically becomes lost in the city, visiting places where something happened but has left no trace: «I visited each of the sites described in the scraps of literature, the places where all the occurences occurred. For several weekends I wandered in scraggy arse-end streets in north or south London, or sometimes in sedate avenues, even once (...) walking through the centre of Soho» (Miéville, 2005: 74). But in the end it is the feral street that is the new flâneur, a stroller and traveller who does not recognize or accept borders. Furthermore, it transcends the world of material goods and environment, consequently transforming the city into a gothic place, one that is labyrinthine and haunted by inconceivable beings. 


\section{The Psychogeographic Network of London: Peter Ackroyd's Hawksmoor}

Peter Ackroyd's Hawksmoor (1985) is a detective and occult serial killer novel that shows considerable parallels to Jack the Ripper narratives - especially the ones following the «royal conspiracy»— theory formulated in Stephen Knight's treatise Jack the Ripper: The Final Solution (1976), famously interpreted in Alan Moore and Eddie Campbell's sixteen part comic series From Hell (1991-98) (Meteling, 2011). The novel tells the story of two characters who are positioned as doubles. One is the architect Nicholas Dyer who is the assistant to the city builder of London, the historical Sir Christopher Wren, from 1684 to 1700. Furthermore, he is a direct reference to the equally famous historical architect Nicholas Hawksmoor. This name is transposed into the novel's timeline of the 1980s and is used for the police detective who investigates several murders committed in or near the churches built by Dyer. The novel's chapter structure can be described as alternating. The odd-numbered chapters of the novel are narrated in the first person, in a language simulating eighteenth-century speech. The narrator of these chapters is the architect Dyer who builds seven churches in London and infuses them with the occult power of his satanic faith by committing ritual murders: «Thus in 1711, the ninth year of the reign of Queen Anne, an Act of Parliament was passed to erect seven new Parish Churches in the Cities of London and Westminster (...). And the time came when Nicholas Dyer, architect, began to construct a model of the first church» (Ackroyd, 1993: 1). Even-numbered chapters report the investigations of police inspector Hawksmoor. The beginning of a chapter always repeats keywords from the end of the previous one, echoing events and ideas from the past to the present and vice versa - thereby insinuating the idea of echoes throughout time. Furthermore, both characters share some traits, visit the same places in the same order and know people with the same name. It becomes clear very early on that the murders in the present are directly connected to the human sacrifices made in the eighteenth century.

Even more than in Gaiman's Neverwhere and Miéville's «Reports of Certain Events in London» the London in Hawksmoor is described in a realistic tone. Despite the fantastic fact that there are two corresponding timelines and that the main characters are time-displaced doubles, everything about the city seems to be rather normal. What is striking is the fact that the London portrayed is characterized by poverty, crime and life on the street. The inhospitable conditions in the eighteenth century are especially pointed out, but the stress is also on the homeless people who are always present in the 
churches of the twentieth century. One could argue that the representation of the city is dominated by the representation of social grievances. So the novel might be something of a social problem novel in visibly staging the city's social problems as its dark side. However, Hawksmoor is no realistic novel, for Dyer's occult powers are unquestionably real. His famous churches are revealed as latent memorials capable of storing the invisible power written into them by human sacrifices and ready to unfold their effects in the contemporary of the twentieth century.

Ackroyd's novel heavily leans on the topographical concept (and actual map) in Iain Sinclair's prose poem Lud Heat (1995), especially the first part «Nicholas Hawksmoor, His Churches». Both texts can be attributed to the urban political movement and literature of «psychogeography». The term and concept can be traced back to Guy Debord and the Situationist International in the 1950s. It is about life in the city, about its aesthetic and political aspects and especially about the influence specific topographies of the city have on the way of living. In essence, psychogeography is concerned with the influence of places and spaces and the influence that geography, topography and architecture have on the psyche and the unconscious, thus it deals with the nonpersonal — be it environmental or architectural — agency that affects human behaviour. Merlin Coverley summarizes: «Psychogeography is, as the name suggests, the point at which psychology and geography collide, a means of exploring the behavioural impact of urban place» (Coverley, 2006: 10).

The protagonists of psychogeography are defined by their main activity -namely wandering or strolling through the city like the nineteenth-century flâneurs in Paris or London, as Walter Benjamin sketched them, for example, in his texts on Charles Baudelaire, on surrealism or in his Arcades Project (1927-40). But the psychogeography as it is practiced in London in the 1970s and 1980s, as for example by Sinclair, pursues a different direction than the French political movement of the 1950s. It is all about an occult experience of urban space and even accepts esoterical concepts such as ley lines, geological lines of magical power which overlay the Earth and intersect at particular nexus points where previous cultures have established their cultic places. This magical geo- or topo-graphical approach believes that certain places are able to store and release energies which invariably leads to an occult remapping of London. Futhermore, certain rituals are believed to concentrate invisible energies - like the magically infused churches by Hawksmoor in Sinclair or by Dyer in Ackroyd: 
A triangle is formed between Christ Church, St George-in-the-East and St Anne, Limehouse. These are centres of power for those territories; sentinel, sphinxform, slack dynamos abandoned as the culture they supported goes into retreat. The power remains latent, the frustration mounts on a current of animal magnetism, and victims are still claimed. (...) From what is known of Hawksmoor it is possible to imagine that he did work a code into the buildings, knowingly or unknowingly, templates of meaning, bands of continuing ritual. The building should be a Temple, an active place, a high metaphor. The buildings taken together, knotted across the city, yield a further word. (...) his churches are the mediums, filled with the dust of wooden voices (Sinclair, 1995: 15-17).

In Ackroyd's novel, the historical architect Hawksmoor is transformed into the ritual murderer Dyer while the fictitious detective takes over the historical name «Hawksmoor». But Hawksmoor is not a historical novel, for it invents the architect's seventh church, Little St Hugh. In the end, the novel also leaves its largely realistic setting behind and stage-manages an overlapping of the two temporally distant doppelgängers as an act of transcendent merging, a deliverance from temporality itself. However, while the notion of time is then abandoned the notion of space becomes even more important. For in the novel (as well as in Sinclair's prose poem) everything is about the exact fulfilment of spatial constellations, the power that is provided by certain architectural patterns in London in mirroring — according to mediaeval beliefs - specific cosmic and occult orders:

And thus will I compleet the Figure: Spittle-Fields, Wapping and Limehouse have made the Triangle; Bloomsbury and St Mary Woolnoth have next created the major Pentacle-starre; and, with Greenwich, all these will form the Sextuple abode of Baal-Berith or the Lord of the Covenant. Then, with the church of Little St Hugh, the Septilateral Figure will rise about Black Step Lane (...) the seven Churches are built in conjunction with the seven Planets in the lower Orbs of Heaven, the seven Circles of the Heavens, the seven Starres in Ursa Minor and the seven Starres in the Pleiades. Little St Hugh was flung in the Pitte with the seven Marks upon his Hands, Feet, Sides and Breast which thus exhibit the seven Demons (Ackroyd, 1993: 186).

In Hawskmoor, the psychogeographic and occult imagination is the invisible centre of the story. On the one hand the novel tells a more or less conventional story with clear connections to the detective and thriller genre, albeit in two timelines, on the other hand, it continues certain gothic traditions and finally reaches an ending that is full-blown fantastic, as it merges the two characters and thus the two time periods in order to create a space without 
time. The story does this by exploiting the spatial concepts of London psychogeography and intertwines its ideas with a very specific concept of time combined with the trope of the satanic ritual murder - mirroring some famous interpretations of the Jack the Ripper murders. In short, the concept of a magical urban topography is considered a power that may not only lead to violence but as it all happens in the guise of a detective novel the violence is directed against rationalism, linear thinking and the notion of enlightenment.

In his Biography of London Peter Ackroyd shifts the focus of the investigation of the Jack the Ripper murder from the concept of looking for a single murderer to the crime scene and then to the revelation that the city of London might be one of the perpetrators, «as if the city itself might have taken part in the crime» (Ackroyd, 2003: 264). He concludes: «The real murderers were never discovered, but it would seem that the topography of London itself played a fortuitous if malign part» (Ackroyd, 2003: 265). According to this explanation Jack the Ripper becomes an «enduring aspect of London myth, with the areas of Spitalfields and Whitechapel as the dark accomplices of the crimes» (Ackroyd, 2003: 265). The fictional Hawksmoor is the literary equivalent to these ideas, for it leaves all conventions of a detective or serial killer novel behind. There is nothing to solve, there is neither chronology nor causality between murder and investigation, between cause and effect. Time itself is transcended in Hawksmoor so there is no beginning and no ending, only doubles and repercussions through time, echoes which have effects in the present as well as the past. Dyer - one fiendish interpretation of the historical architect Hawksmoor - and the fictional detective Hawksmoor are the same character, finally merging in the end, and London is established as a heterotopical place of magical power, annihilating enlightened rationalism since its beginning in the eighteenth century as well as the twentieth century. Only the notion of space is still important -in the magical shape of the constellations of the seven churches and, of course, the city of London.

\section{The Gothic Space of London}

Urban fantasy has much in common with the tradition of gothic literature, as it ponders the rules of literary space and especially deals with the notions of borders, liminality and heterotopia. In urban fantasy like Gaiman's, Miéville's or Ackroyd's the narrative is almost always about different and often mutually exclusive worlds. In Neverwhere the people of London Above are 
not able to perceive the people belonging to London Below. This is a diegetic device that more or less leads to an allegorical reading of the novel as addressing social problems about the poor, the abandoned and the homeless. In Miéville's story the secret life of animated streets is totally unrecognizable for the uninitiated. Only an expert sees the difference in urban space that is produced by wandering streets. While this expert of streets somewhat echoes the nineteenth-century urban character of the flâneur, the story's archival structure also reminds of a mythopoetic dynamic like the one that can be found in Lovecraft's «Cthulhu Mythos». Hawksmoor finally deals with two parallel timescapes in the London of the eighteenth and twentieth century which are inexplicably overlapping and intertwined.

Regarding the importance of space in urban fantasy one of its predecessors seems to be the gothic novel of the eighteenth century. Gothic literature's most important feature is, as its name reveals, the correspondence of emotion with space, architecture and interior. The horror or uneasiness the gothic novel may convey is not only achieved by describing horrific events but by evoking a certain mood or atmosphere created by haunted castles, abbeys and mansions, by the implementations of graveyards, dark attics and dungeons and by the general notion of ruin, decay and madness.

Significantly, the first gothic novel, Horace Walpole's The Castle of Otranto (1764), is named after its setting, the haunted castle. Furthermore, in the preface (in the guise of an anonymous editor) Walpole stresses the realism of the location:

Though the machinery is invention, and the names of the actors imaginary, I cannot but believe that the ground-work of the story is founded on truth. The scene is undoubtedly laid in some real castle. The author seems frequently, without design, to describe particular parts. The chamber, says he, on the right-hand; the door on the left-hand; the distance from the chapel to Conrad's apartment: these and other passages are strong presumptions that the author had some certain building in his eye (Walpole, 2001: 7).

Considering the fact that the novel is a fantastic one with supernatural effects that border on the comical and the grotesque (including a giant helmet falling from the sky and killing the villain's son), the need for spatial authenticity of the castle proves its importance. The castle is described, for example, as a «long labyrinth of darkness» (Walpole, 2001: 61), in which «now and then some blasts of wind (...) shook the doors they had passed, and which grating on the rusty hinges were re-echoed» (Walpole, 2001: 61). Dark subterranean 
rooms such as the corridors, the cave in the forest and especially the chapel, are pivotal places in the text. They are the stages for enlightenment and anagnorisis, but even more they are places of fatal misunderstandings and confinement. While Isabella, the damsel in distress, for example, tries to flee from the villain Manfred, she invariably lands in the vaults, «as she recollected a subterraneous passage which led from the vaults of the castle to the church of saint Nicholas» (Walpole, 2001: 61).

Since its reformulation in the nineteenth century, the dark and brooding atmosphere of haunted houses and castles in gothic novels increasingly reflects the inner conflicts of their characters. With Edgar Allan Poe's 1839 story «The Fall of the House of Usher» the gothic tale establishes the notion of an almost corporeal connection between the protagonists and the buildings they live in. Roderick Usher's decadent and fragile mind mirrors exactly the brittle state of his house and vice versa. As soon as one is starting to break down, the other does as well. Most modern ghost novels adopt this gothic correspondence between the characters' psyches and the haunted buildings, sometimes transforming the house itself into a storehouse of repressed memories and thereby anthropomorphizing it —most prominently done in Shirley Jackson's 1959 ghost novel The Haunting of Hill House (1959) and Stephen King's novel The Shining (1977).

The gothic tradition is continued in the urban fantasy genre. It uses the more or less subtle correspondences between characters and the spaces they inhabit, even to the extent that the space itself is somehow animated by some genius loci or functions as a storage for memories, as Door in Neverwhere puts it: «Memories (...) They're imprinted in the walls» (Gaiman, 2016: 91). In urban fantasy everything happens on a much larger scale, of course. It is about the urban landscape and mostly about the fact that this dense and civilized place of culture has turned into a place of nature or even into a dangerous and labyrinthine jungle. Urban fantasy is not about a limited and clearly arranged personnel, a family or an individual with a past dark secret, but it is always about (post-)modern society and politics. Furthermore, while in gothic novels the spatial notions often correspond to temporal ones, thereby connecting the present with the past, urban fantasy tells about different spaces, worlds or planes of existence as metaphors for different perspectives on the world -in a literal as well as a figurative way. What the gothic castle or haunted house of the gothic novel shares with the city of urban fantasy is the fact that they can be characterized as heterotopias, places that, according to Michel Foucault, represent and concentrate the epistemologies and power structures of a culture and refer to possible alternatives (Foucault, 1984). As haunted or fantastic 
places they clearly connect the referential with the imaginary and therefore are able to show the borders of transition or even the possibilities of redemption or revolution. While the gothic novel with its family secrets and ghosts is clearly about the past, urban fantasy is about the present and - disguised as a fantastic alternative- about the possibilities for the future.

\section{BIBLIOGRAPHY}

Ackroyd, Peter (2003): London: The Biography, Anchor, New York.

- (1993): Hawksmoor, Penguin, London.

BenjAmin, Walter (1992): Charles Baudelaire: Ein Lyriker im Zeitalter des Hockapitalismus, Suhrkamp, Frankfurt am Main.

CAmpbell, Joseph (2008(2008): The Hero with a Thousand Faces, New World Library, Novato, CA.

Coverley, Merlin (2006): Psychogeography, Pocket Essentials, Harpenden.

Foucault, Michel (1984): «Of Other Spaces, Heterotopias», available at https: / / foucault. info/doc/documents / heterotopia/ foucault-heterotopia-en-html [02.24.2017].

Freud, Sigmund(1991): On Metapsychology - The Theory of Psychoanalysis: Beyond the Pleasure Principle, The Ego and the Id and Other Works, Penguin, London.

Gaiman, Neil (2016): Neverwhere: Author's Preferred Text, Morrow, New York.

JAMESON, Fredric (1991): Postmodernism, or, The Cultural Logic of Late Capitalism, Duke University Press, Durham, NC.

KNIGHT, Stephen (1976): Jack the Ripper: The Final Solution, Harrap, London.

LATOUR, Bruno (2007): Reassembling the Social: An Introduction to Actor-Network Theory, Oxford University Press, Oxford.

Larrabeiti, Michael (2002): The Borrible Trilogy. Introduction by China Miéville, Tor Books, London.

Lovecraft, Howard Phillips (1985): «The Call of Cthulhu», in The H. P. Lovecraft Omnibus 3: The Haunter of the Dark and Other Tales, Harper Collins, London, pp. 61-98.

Mendesonn, Farah, \& Edward James (2009): A Short History of Fantasy, Middlesex University Press, London.

Meteling, Arno (2014): «Krieg und Kartographie. Einführung in die epische Fantasy», in Michael Dellwing and Martin Harbusch (eds), Vergemeinschaftung in Zeiten der Zombie-Apokalypse. Gesellschaftskonstruktionen am fantastischen Anderen, Springer, Wien/New York, pp. 37-68. <https:/ / doi.org/10.1007/978-3-658-01722-4_3>

— (2011): «Jack the Ripper und die Verschwörung des Raums: Psychogeographisches Mapping bei Alan Moore, Peter Ackroyd und Iain Sinclair», in M. Krause, A. Meteling \& M. Stauff (eds), The Parallax View: Zur Mediologie der Verschwörung, Wilhelm Fink, München, pp. 295-312.

Miéville, China (2005): «Reports of Certain Events in London», in Looking for Jake and Other Stories, Macmillan, London, pp. 53-77. 
Moorcock, Michael (1978): «Epic Pooh», pp. 1-5, available at <http:/ / www.revolutionsf. com/article.php?id=953> [02.24.2017].

SinClaIr, Ian (1995): Lud Heat: With an Introduction by Michael Moorcock and Maps by Dave McKean. Suicide Bridge, Vintage, London.

TolKIEN, J.R.R. (1991): «Foreword», in The Lord of the Rings, Grafton, London, pp. 9-12.

- (1947): «On Fairy-Stories», in C. Tolkien (ed.), The Monsters and the Critics and other Essays, Harper Collins, London, pp. 109-161.

Walpole, Horace (2001): The Castle of Otranto, Penguin, London. 